\title{
Kant and Teleological Ethics. $\left.{ }^{1}\right)$
}

\author{
By Frank Thilly, University of Missouri.
}

The goal at which every system of ethics aims, is the discovery of a principle of morality, that is, to give a satisfactory answer to the question, What shall I do? How ought I to act? For the ancient Greeks the problem assumed the form of an inquiry into the highest good. By the highest good they meant the highest end or purpose, something which has absolute worth, which is desired not for the sake of something else, but for its own sake, unconditionally. Aristotle expresses the idea in a celebrated passage: „As it appears that there are more ends than one, and some of these, e. g., wealth, flutes, and instruments generally, we desire as means to something else, it is evident that they are not all final ends. But the highest good is clearly something final. Hence, if there is only one final end, this will be the object of which we are in search, and if there are more than one, it will be the most final of them. We speak of that which is sought after for its own sake as more final than that which is sought after as a means to something else; we speak of that which is never desired as a means to something else as more final than the things which are desired both in themselves and as a means to something else; - and we speak of a thing as absolutely final, if it is always desired in itself and never as a means to something else" ${ }^{2}$ ).

1) A paper read before the American Philosophical Association, Columbia University, New-York, at its first meeting, April 1, 1902. See the Report of the Secretary "The Philos. Review". XI, 3, 279.

2) Nicomachean Ethics, Bk. I chap.'V, Welldon's translation. See . also Plato, Philebus, $20 \mathrm{ff}$. 
For the Greeks, then, the highest good was the principle or criterion by which they judged of actions. Modern thinkers approach the problem of ethics from a different side, perhaps, but they, too, endeavor to find a criterion which will enable them to distinguish between right and wrong conduct. Thus, there is a school of moralists which examines so-called right and wrong acts, and finds that acts are right or wrong because they tend to produce certain effects or realize certain ends. The hedonists say, this end is pleasure or happiness; the perfectionists seek it in perfection or development or progress. Their reasoning is somewhat as follows: Such and such an act is wrong because it tends to hinder the realization of such and such an end, say happiness or welfare. I ought not to perform such acts because they make against this end. The end or purpose itself, however, these thinkers do not attempt to justify, because it cannot be justified or proved. The act is right or wrong because of the end realized or not realized by it, but the end or purpose is something that has absolute worth, it is desired and approved for its own sake. John Stuart Mill, for example, agrees with Aristotle when he says: "Questions of ultimate ends are not amenable to direct proof. Whatever can be proved to be good must be so by being shown to be a means to something admitted to be good without proof. The medical art is proved to be good by its conducing to health; but how is it possible to prove that health is good? The art of music is good for the reason, among others, that it produces pleasure; but what proof is it possible to give that pleasure is good? " 1 )

In short, the attempt is made in ethics to discover a principle which is self-evident in the sense that everyone will accept it, which no human being will reject, or at any rate, which socalled normal human beings accept or unconsciously obey in their judgment of actions. According to this view, the particular acts are good or bad according to the effects which they tend to produce. The moral laws serve a purpose; they are means to an end; not absolute, but relative. They are, in the last analysis, commanded or prohibited becanse of their effects; the final ground

1) Mill, Utilitarianism, chap. 1. See also Hume, Principles of Morals, Appendix I, v; Spencer; Data of Ethics, chap. III, $\S 9$; Sigwart, Vorfragen der Ethik, pp. 11 f., Logik, vol. II, pp. 529 ff.; Paulsen, System der Ethik, Bk. II, chap. 1 . 
of their rightness and wrongness lies in the purpose which they serve.

Now this school of thinkers is opposed by those who deny the relative character of morality, and insist upon the absoluteness of the moral law. In our day these moralists scek support from the system of Immanuel Kant, and refer to him as the great adrocate of their position. But it can be shown, it seems to me, that they err in appealing to him, and that his standpoint is by no means as antagonistic to the socalled teleological theory, which I have just described, as is generally assumed. Kant's method of procedure differs from that employed by most modern thinkers, but his results do not differ much from theirs after all. He, too, is seeking for a principle upon which to base morality, and tries to find one that will prove acceptable to every rational human being. "Gegenwärtige Grundlegung ist aber nichts mehr", he says, „als die Aufsuchung und Festsetzung des obersten Princips der Moralität, welche allein ein, in seiner $A b$ sicht, ganzes und von allen anderen sittlichen Untersuchungen abzusonderndes Geschäft ausmacht"1). But while they examine the particular moral acts and attempt to read the supreme principle out of them, Kant, true to his rationalistic proclivities, endeavors to deduce it, a priori, from the notion of a rational being as such. "Also unterscheiden sich die moralischen Gesetze, samt ihren Principien, unter allem praktischen Erkenntnisse von allem Übrigen, darin irgend etwas Empirisches ist, nicht allein wesentlich, sondern alle Moralphilosophie beruht gänzlich auf ihrem reinen Teil, und, auf den Menschen angewandt, entlehnt sie nicht das Mindeste von der Kenntnis desselben (Anthropologie), sondern giebt ihm, als vernünftigem Wesen, Gesetze a priori“, etc. ") He works desperately at this task, and we almost hear him panting for breath in his labors, but the result does not seem to me to differ so much from that of the modern teleologist, as I shall attempt to show in the following. ${ }^{3}$ ) Rosenkranz.

1, Grundlegung zur Metaphysik der Sitten, Vorrede, p. 9,

2) Grundlegung, Vorrede, p. 6. See also Metaphysik der Sitten, pp. 15 f.

3) I have based what follows largely upon the Grundlegung, because I do not believe there is any fundamental difference between this work and Kant's later book, Kritik der pr. Vernunft, so far as the question involved in this article is concerned. 
In the first section of the Grundlegung zur Metaphysik der Sitten, Kant first attacks his problem in a popular way. "Without quitting the moral knowledge of common human reason " 1 ), as he says, he searches for the supreme principle. His line of thought is somewhat as follows: What is the highest good? A good will. What is a good will? One that is actuated by duty. What is duty? Duty is to be determined by the formal. principle of willing. Hence a good will is one that is determined by the formal principle of willing, i. e., not by material desires, not by empirical motives, but by an a priori form. A good will is one that is determined by law, and not by desires or inclinations. I must act from respect for law. But what is this law? What have I left after eliminating all empirical motives? It is this: Act so that you can will the maxim of your willing to become universal law. If I cannot will that my maxim become a universal law, then this maxim must be rejected, not on account of the harm it promises me or some one else, but because it cannot be made to fit into a possible universal legislation as a principle. This universal legislation commands my respect, although I do not, as yet, understand upon what this is based. I do know; however, that my evaluation of it far surpasses the value of anything praised by inclination, and that the necessity of my acts from pure respect for the practical law is what constitutes duty. This principle is present in every human consciousness. . And although common men do not conceive it in such an abstract and universal form, yet they always have it before their eyes, and use it as the standard of their decision".

What else does this mean than that morality is grounded in human nature; not in the particular, temporary (empirical) desires of the individual, but in the (a priori) human reason as such? There is present in every rational being a formal principle or law, a principle which is the condition of all morality, which the being respects and sets the highest value on: Act so that you can will the maxim of your conduct to become universal law. Do not lie. Why not? Because you cannot will that lying should become universal. And why not? "So werde ich bald inne, dass ich zwar die Lüge, aber ein allgemeines Gesetz zu lügen gar

1) I frequently follow Abbott's ercellent translations in the course of the paper. 
nicht wollen könne; denn nach einem solchen würde es eigentlich gar kein Versprechen geben, weil es vergeblich wäre, meinen Willen in Ansehung meiner künftigen Handlungen Andern vorzugeben, die diesem Vorgeben doch nicht glauben, oder, wenn sie es übereilter Weise thäten, mich doch mit gleicher Irünze bezahlen würden, mithin meine Maxime, sobald sie zum allgemeinen Gesetz gemacht wïrde, sich selbst zerstören müsse" ${ }^{1}$ ). That is, if everybody lied, there would be no confidence in promises, and lying would lose its raison d'être, and there would be no universal legislation or society. The lie is wrong, not because it may happen to injure you or some other person in this particular case, but because the lie as such undermines confidence and hinders the realization of a good which you and every other rational being value for its own sake. The teleological moralist will have no difficulty in accepting these thoughts.

But the philosopher is not satisfied with a mere statement of the principle as it is found even in the commonest man. The common man, of course, needs no proof of the principle; it would be a sad thing for morality if he did. "We do not need science and philosophy to know what we should do to be honest and good, yea, even wise and virtuous". The thinker, however, who endeavors to construct a system of morality, must show the logical necessity of the truths he presents. The principle spoken of, is not derived from experience, says Kant; it is a priori and must be proved by a priori reasoning. We cannot derive morality from examples, we need a priori principles, that is, we need a metaphysic of morals, which will give us universal and necessary knowledge. „Aus dem Angefuihrten erhellt, dass alle sittlichen Begriffe völlig a priori in der Vernunft ihren Sitz und Ursprung haben, und dieses zwar in der gemeinsten Menschenvernunft ebensowohl, als der im höchsten Masse spekulativen; dass sie von keinem empirischen und darum bloss zufällige Erkenntnisse abstrahiert werden können; - dass es nicht allein die grösste Notwendigkeit in theoretischer Absicht, wenn es bloss auf Spekulation ankommt, erfordere, sondern auch von der grössten praktischen Wichtigkeit sei, ihre Begriffe und G'esetze aus reiner Vernunft zu schöpfen, rein und unvermengt vorzutragen; ja den Umfang dieses ganzen praktischen oder reinen Vernunfterkenntnisses,

1) Grundlegung, p. 24, R. 
d. i. das ganze Vermögen der reinen praktischen Vernunft, zu bestimmen, hierin aber nicht, wie es wohl die spekulative Philosophie erlaubt, ja bisweilen notwendig findet, die Prinzipien von der besondern Natur der menschlichen Veruunft abhängig zu machen, sondern darum, weil moralische Gesetze für jedes vernünftige Wesen überhaupt gelten sollen, sie schon aus dem allgemeinen Begriffe eines vernünftigen Wesens überhaupt abzuleiten, und auf solche Weise alle Moral, die zu ihrer Anwendung auf Menschen der Anthropologie bedarf, zuerst unabhängig von dieser als reine Philosophie, d. i. als Metaphysik, vollständig vorzutragen" ${ }^{1}$ ).

The problem is to deduce morality from the conception of a rational being as such. This Kant struggles heroically to do in the second section of the Grundlegung. A rational being, he finds, is one that has power to act according to the conception of laws, i. e., a will. When reason determines the will inevitably, then the acts of the rational being are subjectively necessary. But in human beings the will is not determined sufficiently by reason alone, it does not completely accord with reason; hence their acts are subjectively contingent; the will does not of necessity follow the principles of reason. Hence we have here in such a will obligation (Nöthigung). The conception of an objective principle which is obligatory for a will, in the way just shown, is a command, and the command is expressed in imperative form. There are two kinds of imperatives, hypothetical and categorical. The hypothetical imperative does not command the action absolutely, but only as a means to another purpose. The categorical imperative commands a certain conduct immediately, without having as its condition any other purpose to be attained by it. It concerns not the matter of the action, or its intended result, but its form and the principle of which it is itself the result.

Now the important question arises, Is there really such an imperative as this? We cannot determine this empirically from examples, says Kant; the existence of the imperative must be proved a priori, that is, must be shown to follow necessarily from the conception of a rational being. But before this difficult task can be performed, we must first inform ourselves concerning the content of the imperative. We can deduce this content a priori from the notion of a categorical imperative, that is, its

1) Grundlegung, R., pp. 34 f. 
content will follow logically from the very notion of it. When I think a categorical imperative, I know at once what it contains. It contains the injunction: "Act only on that maxim whereby thou canst at the same time will that it should become a universal law". Or it may also be expressed as follows: "Act as if the maxim of thy action were to become by thy will a Universal Law of Nature". Let us now note the application of this principle, to particular examples. You cannot will to take your life, because you cannot will that the maxim prompting the deed, which would be self-love in this case, should become a universal law. You cannot will to break your promises, because you cannot will that such a breach become universal. No nature could exist in which the maxim prompting these acts, self-love, became the law. In a third example Kant shows that no one can will that his higher nature be subordinated to his lower. Here he seems to modify the principle somewhat. $\mathrm{He}$ finds that a nature would actually be possible in which persons subordinated their higher functions to the lower, but that no one could will such a nature. Similarly, as is brought out in a fourth example, it would be possible for a nature to exist in which I injured no one, but at the same time contributed nothing to his welfare. However, it would be impossible for me to will such a principle. Why? Because such a will would contradict itself; a person would will that other persons help him, and at the same time he would will not to help others himself. „Einige Handlungen sind so beschaffen, dass ihre Maxime ohne Widerspruch nicht eimmal als allgemeines Naturgesetz gedacht werden kann; weit gefehlt, dass man noch wollen könne, es sollte ein solches werden. Bei Andern ist zwar jene innere Unmöglichkeit nicht anzutreffen, aber ·es ist doch unmöglich, zu wollen, dass ihre Maxime zur Allgemeinheit eines Naturgesetzes erhoben werde, weil ein solcher Wille sich selbst widersprechen würde" 1 ).

The thought here is this: You cannot will suicide and deception to become universal. Why not? Because if they did, a nature (society) would be impossible. Nor can you will to subordinate your own higher powers to the lower. Why not? A nature would be possible in which that were done. But you cannot will that such a nature should exist. Hence certain acts

1) p. 50, R. 
are immoral, not because a nature would be impossible with them, but because a certain nature, one in which the lower wàs subordinated to the higher, would be impossible. Nor can you will merely not to injure anybody; you must help your fellows directly. Why? Because you want others to help you. If you desire them to help you, you must will to do the same for them.

We see, Kant packs into his categorical imperative a content which he really derives from the practical examples before him, and not from the imperative itself, nor from the principle which he believes follows necessarily from the very conception of a categorical imperative. In this way we actually get the following principles: 1) Do nothing that will hinder the realization of the ideal, nature (or society) (the principle of justice); but 2) endeavor to promote it positively (the principle of benevolence); 3) Subordinate your lower self to your reason (the principle of selfcontrol) 1 ).

It must next be proved, a priori, of course, from the nature of a rational being as such, that there is such a categorical imperative as has been described. To do this Kant now begins all over again. He goes back to the conception of a rational being, and tries to spin out of this the desired results. Rational beings have the power to determine themselves according to the conception of laws. This power is called will. The will, therefore, determines itself by an objective principle. Such a principle is a purpose, and, when this purpose follows necessarily from the reason as such, is valid for all rational beings. There are purposes which are means to other purposes, but these are only relative. A purpose which has absolute value is a purpose in itself, an objective purpose. There is such a purpose. Every rational being is a purpose or end in itself. Irrational beings have only relative worth, as means, and are therefore called things. Rational beings are called persons, because they are ends in themselves, and therefore objects of respect. Every rational being conceives itself as such an end in itself, hence this purpose is an objective purpose or end. This purpose is expressed in the imperative form, and as a categorical imperative, because it is an

1) It is interesting to compare with the above, Sidgwick's principles: the principle of rational self-love, the principle of the duty of benevolence, and the principle of justice. See the Methods of Ethics. 
end in itself, a purpose having absolute or unconditional worth. This imperative is: So act as to treat humanity in your own person as well as in the person of every one else always as an end and never as a means merely. In order to be moral your acts must conform to this principle. You must treat humanity as an end in itself; you must promote this end in your own person and in that of others, that is, you must make the end of your fellowman your own.

This purpose cannot be derived from experience, 1) because it is a universal priuciple; 2) because in it humanity is not conceived as the end of men (subjectively), that is, as an object which one of oneself makes one's purpose, but as an objective end, one which, whatever may be our purposes, must, as a law, constitute the highest limiting condition of all subjective ends or purposes. That is, it is not a temporary, empirical or subjective purpose, but the highest end or purpose, one that has absolute value and precedence. Hence the end must spring from pure reason $\left.{ }^{1}\right)$.

According to our first principle, the form of universality is the objective ground of all practical legislation, that is, the formal condition of all morality. The subjective ground is the end or purpose. Now according to our second principle every rational being as an end or purpose in itself, is the subject of all ends. Hence follows the third principle of the will: the idea that the will of every rational being is a universal legislative will. That is, every rational being is an end in itself, the highest end; it gives itself the law. Now the form of all law is universal. Hence every rational being legislates universally. It follows from all this that such a universal will can give a categorical imperative. Man is subject to his own will, but his own will legislates for all. The notion of such a will leads us to the idea of a king$\mathrm{dom}$ of ends, that is, a systematic union of different rational beings by common laws. This notion of a kingdom of ends is only

1) Kant thinks that because this highest end or purpose is a priori or innate in 'man, it cannot be derived from experience. Now the end in itself may not be the product of experience, it may be a priori, yet our knowledge of it might be derived from experience. But Kant will not admit this, because he aims to base morality on an absolute foundation, to make the truths of morality as necessary as those of mathematics, and therefore rejects everything that smacks of empiricism. 
an ideal; but every rational being can become a member of such a kingdom by virtue of its universally legislating will. Hence morality is a reference of all acts to such legislation as would make a kingdom of ends possible. This legislation, however, must be capable of being found in every rational being and spring from its will. The principle of this will is: „Never to act on any maxim which cannot without contradiction be also a universal law, and accordingly always so to act that the will can at the same time regard itself as giving in its maxims universal laws".

We conclude, as we started, with the notion of an absolutely good will. That will is absolutely good which cannot be bad, hence whose maxim cannot contradict itself. Hence this principle is its highest law: "Always act upon a maxim which you can will to become a universal law." The same thought can also be expressed: "Act on maxims which can have as their object themselves as univeral laws of nature". If these principles were universally obeyed, the kingdom of ends would be realized.

But we have not proved the possibility of the categorical imperative after all, Kant now tells us. „Wie ein solcher synthetischer praktischer Satz a priori möglich und warum er notwendig sei, ist eine Aufgabe, deren Auflösung nicht mehr binnen den Grenzen der Metaphysik der Sitten liegt, auch haben wir seine Wahrheit hier nicht behauptet, vielweniger vorgegeben einen Beweis derselben in unserer Gewalt zu haben. Wir zeigten nur durch Entwickelung des einmal allgemein im Schwange gehenden Begriffs der Sittlichkeit, dass eine Autonomie des Willens demselben, unvermeidlicher Weise, anhänge, oder vielmehr zum Grunde liege. Wer also Sittlichkeit für Etwas, und nicht für eine chimärische Idee ohne Wahrheit hält, muss das angeführte Princip derselben zugleich einräumen. Dieser Abschnitt war also, eben so, wie der erste, bloss analytisch. Dass nun Sittlichkeit kein Hirngespinst sei, welches alsdann folgt, wenn der kategorische Imperativ und mit ihm die Autonomie des Willens wahr, und als ein Princip a priori schlechterdings notwendig ist, erfordert einen möglichen synthetischen Gebrauch der reinen praktischen Vernunft, den wir aber nicht wagen dürfen, ohne eine Kritik dieses Vernunftvermögens selbst voranzuschicken, von welcher wir in dem letzten Abschnitte die zu unserer Absicht hinlänglichen Hauptzüge darzustellen haben" ${ }^{1}$ ). The key to the riddle which we are trying

1) R., p. 76. 
to solve is sitid to lie in the conception of freedom. Kant, therefore, tries to deduce the categorical imperative from the notion of freclom. Freclom is a kind of causality of rational beings: it is the power to act independently of foreign causes. Stated positively, the freedom of the will is a u ton o my, the property of the will to be a law to itself. But this is really identical with the formula of the categorical imperative, which reads: Always act on a maxim which can have as an object itself as a universal law. Hence it is plain that if there is freedom of the will, there is morality, that is, the principle of all morality, the categorical imperative, follows necessarily from the conception of free will.

But still the problem is not solved. It must next be proved that all rational beings are free. Kant argues: A being that cannot act otherwise than on the idea of freedom is practically free, that is, all the laws hold for it which are inseparably connected with freedom. Now we must ascribe to every rational being that has a will, the idea of freedom. For we conceive such a being as having a reason which is practical, i. e., has causality. with respect to objects. We cannot think a reason which is controlled in its judgments by foreign causes, for if that were the case, the subject would ascribe its judgments not to its reason, but to something else. It must regard itself as the cause of its principles, independent of foreign influences, hence it must regard itself as practical reason or as the will of a practical being, hence as free. But we cannot really prove this freedom, we must presuppose it when we conceive a being as rational and endowed with the consciousness of freedom.

But we seem to reason in a circle here, according to Kant. First we assume that we are free in order that we may conceive ourselves as subject to moral laws; then we conceive ourselves as subject to these laws because we have assumed that we are free. This difficulty is removed by the introduction ef the conception of an intelligible world. Every rational being regards itself, first, as belonging to the world of sense, and therefore subject to the laws of nature, and, secondly, as belonging to the intelligible world, and hence subject to laws which are independent of nature, not empirical, but grounded in reason alone.

It is not necessary, however, for our purposes, to consider this question of freedom any further. Kant finally concludes that we cannot really prove how the idea of freedom is possible. It 
is possible on the assumption of an intelligible world, but we have no knowledge of such a world. „Die Frage also: wie ein kategorischer Imperativ möglich sei, kann zwar soweit beantwortet werden, als man die einzige Voraussetzung angeben kanu, unter der er allein möglich ist, nämlich die Idee der Freiheit, ingleichen als man die Notwendigkeit dieser Voraussetzung einsehen kann, welches zum praktischen Gebrauche der Vernunft, d. i. zur Überzeugung der von der Gültigkeit dieses Imperativs, mithin auch des sittlichen Gesetzes, hinreichend ist, aber wie diese Voraussetzung. selbst möglich sei, lässt sich durch keine menschliche Vernunft jemals einsehen" 1 ). If we assume the freedom of the will, its antonomy will necessarily follow. It is not only possible to assume this freedom without contradicting the principle of natural causality in the phenomenal world, but it is absolutely necessary for a rational being which is conscious of freedom to assume it practically, i. e., to presuppose it in all its voluntary actions.

We have, in the preceding, frequently compared Kant's ethical teaching with the teleological theory. Let us now gather together the results we have reached with respect to this matter, and present them in somewhat more connected form. According to the teleologist, an act is, in the last analysis, right or wrong, because it does or does not tend to realize a certain end or purpose. This end or purpose itself is something prized for its own sake, something of absolute worth. We cannot explain why human beings prize it as they do; it is a law of their nature. It is a principle common to all human beings, though they are not necessarily clearly conscious of its existence. A certain school of teleologists, called hedonists, teaches that pleasure is the end or purpose described. This view Kant vehemently opposes. There is, however, another school, according to which the end or purpose is not pleasure, but the welfare of humanity, such a development of man's nature that his lower impulses, his material self, shall. be subordinated to his higher powers, his spiritual self, and that he may become a worthy member of society. And that is, in my opinion, exactly what Kant teaches, though he states it in somewhat different language and attempts to prove it in a different way.

$\mathrm{He}$, too, finds in man a principle that is common to all rational beings, a principle over and above his temporary individual

1) p. 96 . 
desires and inclinations, an end or purpose that does not derive its value from something else, but has absolute worth. That is, every rational being conceives itself as an end in itself, meaning by its self not its particular, momentary desires, but that which it has in common with all rational beings, that which makes it a human being. This purpose expresses itself in imperative form: Treat every personality, your own as well as others', as an end in itself and never as a means. That will make possible a kingdom of ends, a union of rational beings, a society. This society would be realized if every man obeyed the dictates of his nature, the categorical imperative. But the ideal cannot be realized without obedience to law. The principle must therefore be observed: Never do anything which you cannot will to become a universal law. That is, the ideal cannot be reached unless every man fulfils the primary condition of its realization. If lying and stealing became universal, there could be no kingdom of ends, no society. You can always judge of the morality of an act by asking yourself whether you would be willing to have everybody do as you do. Its fitness to become a univeral law determines the worth of the act. This principle will hinder you from treating your fellow men as means merely, for you cannot will that they treat you as means. If you treat each other as means, you cannot realize the ideal which you prize above everything else, the ideal of humanity.

Now such acts are, in the last aualysis, moral as make it possible to realize the ideal, the union of rational beings, the kingdom of ends. Not only must we refrain from performing acts which hinder the realization of the ideal, we must also endeavor to promote the ideal directly by positive action, by helping our fellows. And it is not enough to have any union whatever. The highest ideal is a society of a certain kind, a kingdom in which the lower desires and impulses of man are controlled by reason, and in which the individual has regard for the whole. It would be possible, perhaps, to have a society in which every man refrained from injuring his fellows and indulged his lower appetites. But such a union is not Kant's ideal. Even if such a state were possible, we could not will its existence.

It is held by some that Kant eliminates the teleological elements which we have pointed out, in his later work, the Kritik der praktischen Vernunft. Thus Dr. Thon, in a recent work, . 
Die Grundprincipien der Kantischen Moralphilosophie in ihrer Entwickelung, admits that the principle: Act so that you can will the maxim of your action to become universal law, is a disguised eudaemonism, but asserts that the principle is modified in the Kritik der pr. Vernunft in such a manner as to escape this charge. The new reading is: Act so that the maxim of your will can always at the same time hold good as a principle of universal Jegislation. I quote from Dr. Thon: „Ganz anders aber gestaltet sich die Beurteilung des kategorischen Imperativs, wenn in seiner Formel an die Stelle des „Wollen-Könnens“ ein „Gelten-Können“ tritt. Die Entscheidung ist dann nicht mehr subjektiv, sondern objektiv, nicht mehr psychologisch, sondern nur logisch. Der Massstab für die Tauglichkeit der Maxime zum allgemeinen Gesetz liegt dann nur im logischen Satze des Widerspruchs. Hebt sich eine Maxime, wenn sie verallgemeinert wird, nicht selbst auf, $\dot{d}$. h. übergeht sie nicht in ihr kontradiktorisches Gegenteil, dann könnte sie ein allgemeines Gesetz werden, und sie ist daher moralisch-zulässig. Wir nehmen nun das klassische Beispiel Kant's vom Depositum vor. Ich biu im Besitze eines Depositums, dessen Eigentümer gestorben ist, ohne eine Urkunde darüber hinterlassen zu haben. Soll ich es den Erben zurückgeben, oder nicht? Gesetzt, ich würde mir zur Maxime machen, ein Depositum nicht zurückzugeben. Nun versuche ich, diese Maxime zu einem allgemeinen Gesetz auszubauen. Da sehe ich sofort ein, dass sie in ihr kontradiktorisches Gegenteil ïbergeht. Depositum heisst: Die Anlage eines Wertgegenstandes, mit der ausdrücklichen Bedingung der Rückerstattung desselben. Das aus der Verallgemeinerung meiner Maxime hervorgegangene Gesetz würde also lauten: Der Gegenstand, der zurückgegeben werden soll, soll nicht zurückgegeben werden. Meine Maxime taugt also offenbar nicht für ein allgemeines Gesetz und ist somit unmoralisch. Wir haben hier mit reinen Begriffen operiert, die Erfahrung gar nicht zu Hilfe genommen, und die Formel hat sich doch als zuverlässig erwiesen " ").

I cannot agree with Dr. Thon. I do not believe that Kant intended to modify the principle in his later work in the manner indicated by Dr. Thon, but simply to state it more concisely and accurately. I see no, great difference between the examples of

1) pp. $63-64$. 
the application of this principle, as given, say, on pages 137 , 15) f., and 192, of Jiosentiranz's edition of the Kritik der praktischen Vernunft, and the corresponding examples in the earlier work. Thus Kant says on page 159: „Eben so wird die Naxime, die ich in Ansehung der freien Disposition über mein Leben nehme, sofort bestimmt, wenn ich mich frage, wie sic sein miisste, damit sich eine Natur nach einem Gesetze derselben erhalte. Offenbar wïrle Niemand in eiver solchen Natur sein Leben willkürlich eudigen können, denn eine solche Verfassung würde keine bleibende Naturordnung sein, und so in allen übrigen Fällen". $\mathrm{He}$ likewise says in connection with the deposit-example: I an not willing to make a general law that everyone should keep a deposit provided it cannot be proved that such a deposit has been made. „Ich werde sofort gewahr, dass ein solches Princip, als Gesetz, sich selbst vernichten würde, weil es machen würde, dass es gar kein Depositum gäbe. Ein praktisches Gesetz, das ich dafiir erkenne, muss sich zur allgemeinen Gesetzgebung qualificieren; dies ist ein identischer Satz und also für sich klar. Sage ich nun, mein Wille steht unter einem praktischen Gesetze, so kann ich nicht meine Neigung (z. B. im gegenwärtigen Falle meine Habsucht) als den zu einem allgemeinen praktischen Gesetze schicklichen Bestimmungsgrund desselben anführen: denn diese, weit gefehlt, dass sie zu einer allgemeinen Gesetzgebung tauglich sein sollte, so muss sie vielmehr in der Form eines allgemeinen Gesetzes sich selbst aufreiben. - Denn da sonst ein allgemeines Naturgesetz Alles einstimmig macht, so würde hier, wenn man der Maxime die Allgemeinheit eines Gesetzes geben wollte, gerade das äusserste Widerspiel der Einstimmung, der ärgste Widerstreit und die gänzliche Vernichtung der Maxime selbst und ihrer Absicht erfolgen. Denn der Wille hat alsdann nicht ein und dasselbe Objekt, sondern ein Jeder hat das seinige (sein eignes Wohlbefinden), welches sich zwar zufälligerweise auch mit Anderer ihren $A b$ sichten, die sie gleichfalls auf sich selbst richten, vertragen kann, aber lange nicht zum Gesetze hinreichend ist, weil die Ausnahmen, die man gelegentlich zu machen befugt ist, endlos sind, und gar nicht bestimmt in eine allgemeine Regel befasst werden können".

I do not see that there would be any logical contradiction in keeping a deposit, as Dr. Thon asserts. Suppose we define a deposit as something which is given one man by another with the understanding that it be returned. Now suppose I refuse to 
return a deposit. I ask myself: What if everybody refused to return a deposit? Well, even if everybody should refuse to return a deposit, a deposit would still remain a deposit. If everybody should refuse to return a deposit, that would not contradict the definition of a deposit by any means. A deposit would still be a deposit. There is no logical contradiction in saying, Let everyone refuse to return what he promised to return. Failure to return deposits, can become a universal law without violating the logical principle of contradiction, but it cannot become a law without defeating its own purpose and making social life impossible. If no one ever returned a deposit, no one would ever make one, no one would trust any one else, and the ideal, the kingdom of ends, would not be realized. Hence why not keep deposits? Because of the effect which failure to restore his rightful property to an owner would tend to produce.

Kant's standpoint may safely be characterized as teleological. The difference between his theory and that of the modern teleological moralist is one of method. Kant attempts to follow the old rationalistic method, to construct a logic-proof system, after the manner of mathematics, to deduce from principles that are universal and necessary (a priori), other truthis having the same absolute validity. This he is particularly anxious to do in his ethical inquiries. He endeavors to base the truths of ethics upon an absolutely sure foundation, a task which in his opiniom, empiricism is utterly unable to perform. The moral laws must not only seem absolute to the common man, but must be proved to be to by the philosopher. In order to realize this rationalistic ideal and to deduce every possible moral truth from the conception of a ratiunal being as such, Kant is, of course, compelled to give this conception the content which he afterwards draws out of it, or to pretend that something follows from his so-called first principles that does not follow at all. Thus the content of the categorical imperative cannot be derived from the conception of such an imperative without the application of force. Nor is it possible to deduce from the conception of a rational being what its purpose is, unless we first read that purpose into our definition of such a being. It is, of course, possible to define a rational being in such a way as to make it the bearer of any kind and any number of qualities we choose, but in any event the definition will ultimately have to rest upon experience in order to have any 
value at all. The modern teleogist examines the laws which human beings accept as moral and analyzes the mental states to which they owe their existence. By reflection upon experience he hopes to reach the principle or principles upon which morality is based, and may then attempt to deduce from these their logical consequences. In other words, he employs the methods followed by all sciences, and his results have the same value as those of any other branch of scientific knowledge, no more, no less. 